\title{
Difficulties Faced by Science Teachers in Selected Public Schools in Kuwait: A Descriptive Study
}

\author{
Ebrahim Abdullah Al-Kandari \\ Saed bin Al-Aas Intermediate School, \\ Kuwait City \\ eb_ra@hotmail.com
}

\author{
Tahraoui Ramdane \\ Kulliyyah of Education, \\ International Islamic University Malaysia \\ Kuala Lumpur \\ murad@iium.edu.my
}

\author{
Mohamad Sahari Nordin \\ Kulliyyah of Education, \\ International Islamic University Malaysia \\ Kuala Lumpur \\ msahari@iium.edu.my
}

\begin{abstract}
This study examined the difficulties experienced by science teachers in selected public secondary schools in the Mubarak Al-Kabeer Governorate in Kuwait. The difficulties they encountered were examined under four aspects: curriculum objectives, student assessment, school management, and science laboratories. Ten schools were randomly selected from a population of 22 schools in the governorate. From the ten schools, seventy-seven science teachers $(\mathrm{N}=77)$ responded to a self-developed questionnaire in Arabic on science teaching difficulties. The questionnaire asked 20 items on the four aspects of science teaching difficulties. Data on the difficulties were summarized as frequencies, percentages, means and standard deviations, while gender differences were determined using chi-squares. The results indicated that both male and female science teachers encountered difficulties with the science curriculum objectives in that they are not clear and do not encompass the important learning domains, i.e. the cognitive, affective, and psychomotor domains. Teachers also found the objectives to lack a systematic order that should range from the lowest to the highest. In regard to assessment, teachers experienced difficulties caused by inconsistent and non-standardized practices, as well as by the lack of alignment between curriculum objectives and assessment practices. Authoritarianism and inflexibility in the school management, and the lack of opportunities for professional growth posed further difficulties for teachers. As for science laboratories, a majority of science teachers reported that they lack good equipment, are located in unsafe places, and do not meet safety standards. No significant gender differences were detected in the teachers' perceptions of difficulties, which was taken to reflect the reality on the ground. That is, the difficulties faced by the teachers were not a function of gender. Based on the results, the study recommends that the science curriculum objectives be reformulated to cover all learning domains, and a consistent student assessment system that is aligned to the curriculum objectives be applied. Outdated and negative school management styles must also be replaced by a democratic style that is positive and motivating.
\end{abstract}

Keywords: Kuwaiti science teachers, difficulties in teaching science, student assessment in science, school management, science laboratories, science curriculum objectives 


\section{INTRODUCTION}

Education is a powerful weapon that has the ability to change the world (Simons, 2016). As an integral part of the education system, teachers play a vital role in the change process--in shaping the future generation and providing them with the required knowledge and skills to face challenges of the 21st century. According to Habib (2017) and Kola, Sunday and Ayinde (2015), effective teachers motivate students and consider individual differences as factors that enrich classroom learning experiences. Teacher effectiveness contributes greatly to students' achievement and helps raise a school's academic performance and standards. Given its importance, many researchers are interested in studying teacher effectiveness with the aim of improving the performance of students and schools, specifically in critical subjects such as science and mathematics (Goe, Bell \& Little, 2008; Habib, 2017; Johnson \& Wells, 2017; Marulcu \& Bozkus, 2017; Owoh, 2016; Robinson \& Lewis, 2017).

In Kuwait, students of science face learning difficulties that affect their performance and decrease their motivation towards the subject. This was demonstrated by the results of TIMSS (The Trends in International Mathematics and Science Study) 2015 in which Kuwait participated alongside 38 other countries and ranked 33rd. In addition, Kuwait's science performance in 2015 was significantly lower than what it achieved in 2007 (Martin, Mullis, Foy \& Hooper, 2016). Furthermore, according to the country's General Secretariat of the Supreme Council for Planning and Development (2016), Kuwait ranked 99th globally in the Quality Index of Mathematics and Science Education (out of 140 countries), despite the fact that the Kuwaiti government's spending on educational activities had reached a record high. In the same report, based on an exploratory study that involved public secondary schools in Kuwait, it was documented that Kuwaiti students lacked an interest in science, and that $66 \%$ felt bored in science classes.

An effective teacher with good qualifications and skills can reduce students' learning difficulties in a number of ways. For instance, they can do so by motivating and challenging students' mindsets, developing science competencies and critical thinking, raising their abilities to problem solve, enhancing classroom interaction, and inspiring them to gain the maximum amount of knowledge from teachers (Kola et al., 2015). Since teachers who are effective play an important role in ensuring students' success in learning, their inability to perform well in teaching--as a result of difficulties and obstacles--is a serious concern to many. Therefore, many researchers have taken it upon themselves to study the obstacles and difficulties that affect science teachers' performance, particularly their instructional quality, the lack of which will obstruct students' understanding of science (Anderman, Sinatra, \& Gray, 2012; Chavan, 2013; Stutchbury \& Katabaro, 2011).

\section{Science Teaching Difficulties}

Multiple studies on the challenges occurring in science classes (Kaptan \& Timurlenk, 2012; Kadbey, Dickson \& McMinn, 2015; Parker, Sei-Himah, Asare \& Ackah, 2018) have pointed to debilitating factors such as insufficient equipment and poor physical conditions of science laboratories, teachers' lack of in-service training, and absence of professional development and support. Cansiz and Cansiz (2015) found that science teachers have difficulties with assessment--they are unclear about how students' science understanding should be assessed--and with classroom management. These difficulties are caused by a lack of pedagogical training and classroom exposure. 
Some schools may even be in a far worse state than others in that they do not even have proper science laboratories (Adu-Gyamfi, 2014). This is a factor that severely limits students' opportunity to experience inquiry, an activity that critically influences how much students can grasp scientific concepts. As indicated by research, inquiry is a constructivist approach to science learning that helps students to construct meaning from scientific phenomena, hence enabling them to acquire deep conceptual understanding (YouthLearn, 2016). In cases where they $d o$ have access to a science lab, the lab's poor or insufficient equipment is a hindering factor to science learning success. The absence of proper equipment for lab work was reported by $69.2 \%$ of science teachers in Adwan (1999). On top of this, the absence of a lab technician poses yet another challenge. In Mahmoud (2010), 54.3\% of science teachers felt their teaching was affected by the school's inability to provide lab assistants.

In Sabah (1998), 62\% of the science teachers surveyed felt that their school management failed to create a conducive environment that could bring about science learning confidence in students. In some school systems, science teachers must deal with an authoritarian management (Alotabi, 2007). Such a management is known to restrict teachers' creativity and autonomy, two elements that contribute to general teacher effectiveness.

In addition to feeling disappointed with prevailing systems of student assessment, which many felt was a major obstacle to their instructional effectiveness, teachers also perceived a large gap between the curriculum objectives and curriculum content (Sabah, 1998). What teachers implemented in science classes was ill-aligned with what the science curriculum intended to achieve. Thus, teachers were seen as ineffective when what they managed to achieve fell short of the stipulated learning standards.

Al Enizi (2009) pointed out an important issue with science curriculum objectives; they tend to focus only on outcomes in the cognitive domain. In an earlier study, this tendency was observed by Al Kandari (2006), who noted a 91.2\% emphasis on cognitive learning outcomes and objectives in the science curriculum. On top of that, he also found $95.2 \%$ of the objectives to be focusing on the lowest level of cognitive learning, i.e. the level of knowledge or remember. Adding to this issue is the fact teachers have found science curriculum objectives to be vague. This causes yet another issue in the classroom, i.e. how to deliver science instruction and assess learning appropriately when the objectives are not explicit. Therefore, there is a need to make the objectives of science teaching clearer for teachers in order to render science learning more meaningful for students.

Student assessment has been identified as one of the major reasons contributing to poor achievement in standardized science tests, such as TIMSS and PISA (Dagher \& BouJaoude, 2011). Researchers have also noted a gap between curriculum objectives and the assessment system which has resulted in negative washback. A conclusion that may be reached based on the existing research evidence is that science teachers in many Arab states need a large amount of professional development and better teacher preparation programs to enable them to overcome difficulties in teaching. According to Sabah (1998) and Saleh (1999), male and female science teachers in selected Arab states did not differ significantly in the difficulties they encountered in teaching the subject. This is despite the gender role differences in the Arab culture that affect how men and women perceive things and react to situations.

\section{Research Objectives and Questions}

The major purpose of this study was to find out the difficulties that Kuwaiti science teachers faced in teaching science. The difficulties were examined in terms of four aspects or domains, 
i.e. science curriculum objectives, student assessment, school management, and science laboratories. Further, the study investigated if there were gender differences in the reported difficulties in these four aspects of science teaching. Premised upon these objectives, the main research questions were:

1. What are the difficulties that science teachers in the Mubarak Al-Kabeer governorate schools in Kuwait face in teaching the subject?

2. What difficulties were encountered that specifically related to curriculum objectives, student assessment, school management, and science laboratories?

3. Do the perceived difficulties in these four aspects of science teaching differ significantly between male and female teachers?

\section{METHODOLOGY}

\section{Research Design}

The present study sought to describe the current status, occurrence or prevalence of science teaching difficulties in four aspects: science curriculum objectives, student assessment, school management and science laboratories. Descriptive statistics, i.e. frequencies, percentages, means and standard deviations, were used to profile the occurrence of the difficulties which constituted the phenomena being examined. The data captured in the research instrument were observational data. Therefore, the design of the study was descriptive with some hypothesis testing to check for gender differences in the science teaching difficulties reported by the respondents.

\section{Population and Sample}

The population constituted 120 science teachers from 22 public secondary schools in the Mubarak Al Kabeer governorate in Kuwait. The list of schools was obtained from the registry of the governorate's Science department. The schools were stratified by gender (all-girls and all-boys), and from the stratification, five all-boys and five all-girls schools were randomly selected to participate in the study. From these ten schools, seventy-seven $(\mathrm{N}=77)$ science teachers responded to the survey. They represented $64.2 \%$ of the total population with a margin of error of $\pm 6.7 \%$ and a confidence level of $95 \%$. The resulting sample of 77 respondents comprised 34 male and 43 female science teachers. More details of the population and sample are presented in Table 1.

Table 1

Details of the Population and Sample

\begin{tabular}{ccc}
\hline $\begin{array}{c}\text { Mubarak Al Kabeer } \\
\text { Governorate Areas }\end{array}$ & School Name & $\begin{array}{c}\text { School Selected into the } \\
\text { Study }\end{array}$ \\
\hline
\end{tabular}

All-Boys School

1. Sabah Al Salem a) Hasan Ibn Al-Haytham Essa AL-Loghani

b) Saad Bin Abi Wqas

c) Essa Al-Loghani

2. Al Adan a) Hillal Fajhan Al-Mutairi

Hillal Fajhan Al-Mutairi

b) Ibn Zuhair AL-Andalusi

3. Al Quasor

a) Abdullah Al-Roudhan Abdullah Al-Roudhan

b) Nesef Al-Nesef 

4. AL Quran
a) Al-Quran
Eid Al-Mutairi
b) Eid Al-Mutairi
5. Mubarak AL
a) Abu Al-Qacem Al-Shabi
Ga'afer Bin Abi Talib
Kabeer
b) Ga'afer Bin Abi Talib

All-Girls School

1. Sabah Al Salem

a) Al-Zahra'a

Al-Zahra'a

b) Fatema Bint Abdulmalek

c) Mudhi Al-Obaidi

2. Al Adan

a) Azda Bint Al-Hareth

Azda Bint Al-Hareth

b) Al-Salhya

1. Al Quasor

a) Hassna Bint Muawiya

Hassna Bint Muawiya

b) Hela Botaiban

4. Al Quran

a) Hissa Al-Hanif

b) Hafsa

5. Mubarak AL

a) Al-Qabalia

Kabeer

b) Ramla Om AL-Moamnin

Hafsa

Al-Qabalia

\section{Instrument}

A close ended 20-item questionnaire with four sections on difficulties related to (i) curriculum objectives, (ii) student assessment system, (iii) school management, and (iii) science laboratories was developed and used to collect data for this study. The 20 items were divided into four parts as shown in Table 2:

Table 2

Questionnaire Content

\begin{tabular}{cl}
\hline Part 1 & Difficulties Related to Curriculum Objectives \\
\hline 1 & Unclear Objectives \\
2 & Not considering the surrounding environment \\
3 & Not considering students' ability level \\
4 & Not including all domains (i.e., cognitive, affective and psychomotor) \\
5 & Not following domains levels (i.e., from the lowest order to the highest order) \\
\hline Part 2 & Difficulties Related to Student Assessment \\
\hline 1 & Not following curriculum objectives \\
2 & Not consistently applied \\
4 & Not seeking to develop students \\
5 & Not considering students' individual differences \\
\hline
\end{tabular}

Part 3 Difficulties Related to School Management

1 Giving inconsiderate decisions

2 Authoritarian in dealing with teachers

3 Inflexible in dealing with teachers

$4 \quad$ Not providing the opportunity for teachers' professional growth

$5 \quad$ Not creating confidence in teachers. 


\begin{tabular}{cl}
\hline Part 4 & Difficulties Related to Science Laboratories \\
\hline 1 & Improper design \\
2 & Not meeting safety standards \\
3 & Lacking in equipment \\
4 & Located in unsafe places \\
5 & Laboratory technicians not doing their job properly \\
\hline
\end{tabular}

A five-point Likert scale measuring respondent agreement (i.e., Strongly Agree, Agree, Neutral, Disagree and Strongly Disagree) was used with the 20 items.

\section{Validity and Reliability}

The questionnaire items were content validated by a panel of experts from the Faculty of Education in Kuwait University. Three items, each regarding curriculum objectives, student assessment and science labs, were removed upon the experts' feedback. Two items regarding school management were refined and corrected. In terms of reliability, the Cronbach's alpha values are 0.78 for curriculum objectives, 0.74 for school management, 0.84 for student assessment, and 0.63 for science labs.

\section{Data Analysis}

The data entry and analysis were performed using the SPSS software for Windows 20.0. (SPSS, Chicago, IL, USA). The data were first checked for errors and missing values. Descriptive statistics, i.e. frequencies and percentages, were used to summarise the teachers' responses. The five categories of responses were collapsed into just three: Agree, Neutral and Disagree. Means and standard deviations were also reported for all items. The teachers' responses to each item in the four categories of difficulties were cross-tabulated against the respondent's gender and tested using the non-parametric Chi-square test of significance.

\section{RESULTS}

\section{Difficulties Related to Curriculum Objectives}

Table 3 below shows the difficulties caused by curriculum objectives.

Table 3

Difficulties Related to Curriculum Objectives $(\mathrm{N}=77)$

\begin{tabular}{llccccc}
\hline \multirow{2}{*}{\multicolumn{1}{c}{ Items }} & \multicolumn{4}{c}{ Response Categories } & \multirow{2}{*}{$\mathrm{M}$} & \multirow{2}{*}{$\mathrm{SD}$} \\
\cline { 2 - 5 } & $\mathrm{A}$ & $\mathrm{N}$ & $\mathrm{D}$ & & \\
\hline 1. Unclear objectives & 30 & 23 & 23 & \multirow{2}{*}{3.42} & \multirow{2}{*}{1.35} \\
& $(39)$ & $(29.9)$ & $(29.9)$ & & \\
2. Not considering the & 14 & 13 & 49 & & \\
& surrounding environment & $(18.2)$ & $(16.9)$ & $(63.6)$ & 3.74 & \multirow{2}{*}{1.11} \\
3. Not considering students' level & 17 & 13 & 45 & & \\
& $(22.1)$ & $(16.9)$ & $(58.5)$ & 3.65 & \multirow{2}{*}{1.13} \\
4. Not including all domains & 38 & 19 & 20 & & \\
& $(49.4)$ & $(24.7)$ & $(26)$ & 4.06 & 1.39
\end{tabular}




\begin{tabular}{lccccc} 
5. Not following domain levels & $\begin{array}{c}30 \\
(39)\end{array}$ & $\begin{array}{c}19 \\
(24.7)\end{array}$ & $\begin{array}{c}28 \\
(36.4)\end{array}$ & 3.79 & 1.40 \\
\hline \multicolumn{5}{c}{ Mean for domain } & 3.73 \\
\hline Note: $A=$ Agree $;$ & $N=$ Neutral; $D=$ Disagree $; M=$ Mean $;$ SD = Standard Deviation
\end{tabular}

Almost half of the teachers $(49.4 \%)$ reported that the curriculum objectives do not include all three domains of learning, while $39 \%(\mathrm{n}=30)$ felt the objectives do not follow the domain levels and are unclear. However, a majority disagreed with the suggestion that the objectives do not consider students' level $(58.5 \%)$, and were formulated without considering the surrounding environment $(63.6 \%)$. The pattern of responses shows that the teachers were divided in rating curriculum objectives as problematic and a source of teaching difficulties for them. The only mean score that confirmed the respondents' agreement that the given aspect was problematic for teachers was 4.06, which was recorded for the objectives not including all domains. Another aspect that skewed towards agreement was that the objectives were not following all domain levels $(M=3.79)$. For other items, the responses tend to hover around neutral.

\section{Difficulties Related to Student Assessment}

Table 4 below shows the respondents' agreement to items on the difficulties related to student assessment.

Table 4

Difficulties Related to Student Assessment $(\mathrm{N}=77)$

\begin{tabular}{|c|c|c|c|c|c|c|}
\hline & \multirow{2}{*}{ Items } & \multicolumn{3}{|c|}{ Response Categories } & \multirow{2}{*}{ M } & \multirow{2}{*}{$\mathrm{SD}$} \\
\hline & & A & $\mathrm{N}$ & $\mathrm{D}$ & & \\
\hline 1. & Does not follow curriculum objectives & $\begin{array}{c}45 \\
(58.4)\end{array}$ & $\begin{array}{c}15 \\
(19.5)\end{array}$ & $\begin{array}{c}16 \\
(20.8)\end{array}$ & 3.19 & 1.10 \\
\hline & Is not consistently applied & $\begin{array}{c}44 \\
(57.2)\end{array}$ & $\begin{array}{c}9 \\
(11.7)\end{array}$ & $\begin{array}{c}24 \\
(31.2)\end{array}$ & 2.53 & 1.23 \\
\hline & Does not seek to develop students & $\begin{array}{c}33 \\
(42.9)\end{array}$ & $\begin{array}{c}17 \\
(22.1)\end{array}$ & $\begin{array}{c}27 \\
(35.1)\end{array}$ & 2.57 & 1.55 \\
\hline & $\begin{array}{l}\text { Does not consider students' individual } \\
\text { differences }\end{array}$ & $\begin{array}{c}34 \\
(44.2)\end{array}$ & $\begin{array}{c}12 \\
(15.6)\end{array}$ & $\begin{array}{c}31 \\
(40.3)\end{array}$ & 3.19 & 1.03 \\
\hline \multirow{2}{*}{\multicolumn{2}{|c|}{ 5. Does not follow the standard rules }} & $\begin{array}{c}42 \\
(54.6)\end{array}$ & $\begin{array}{c}23 \\
(29.9)\end{array}$ & $\begin{array}{c}12 \\
(15.6)\end{array}$ & 3.00 & 1.03 \\
\hline & & \multicolumn{3}{|c|}{ Mean for domain } & 2.89 & \\
\hline
\end{tabular}

Higher percentages of agreement, ranging from $58.4 \%$ to $42.9 \%$, were recorded for the difficulties resulting from student assessment. More than half of the teachers reported that the students' assessment system does not follow the stipulated curriculum objectives $(58.4 \%)$, is not consistently applied (57.2\%), and does not follow the standard rules (54.6\%). They further reported that the students assessment system does not consider students' individual differences (44.2\%) and does not seek to develop students (42.9\%). These responses reflect the frustration of science teachers about their inability to objectively assess their students who may have several individual differences using the current Student Assessment System. It also reflects their dissatisfaction with the current system of assessment which does not permit them to develop the academic performance of the students. The mean score for this domain is 2.89 , 
which generally indicates the science teachers' disagreement and dissatisfaction with the existing student assessment system.

\section{Difficulties Caused by School Management}

Item number three attempted to find out the difficulties faced by science teachers caused by school management. Table 5 below indicates the results.

Table 5

Difficulties Caused by School Management $(\mathrm{N}=77)$

\begin{tabular}{|c|c|c|c|c|c|}
\hline \multirow{2}{*}{ Items } & \multicolumn{3}{|c|}{ Response Categories } & \multirow{2}{*}{ M } & \multirow{2}{*}{$\mathrm{SD}$} \\
\hline & A & $\mathrm{N}$ & $\mathrm{D}$ & & \\
\hline $\begin{array}{l}\text { 1. Management with inconsiderate } \\
\text { decisions }\end{array}$ & $\begin{array}{c}38 \\
(39.4)\end{array}$ & $\begin{array}{c}17 \\
(22.1)\end{array}$ & $\begin{array}{c}21 \\
(27.3)\end{array}$ & 3.49 & 1.17 \\
\hline $\begin{array}{l}\text { 2. Authoritarian in dealing with } \\
\text { teachers }\end{array}$ & $\begin{array}{c}52 \\
(67.6)\end{array}$ & $\begin{array}{c}15 \\
(19.5)\end{array}$ & $\begin{array}{c}10 \\
(13)\end{array}$ & 3.31 & 1.05 \\
\hline 3. Inflexible in dealing with teachers & $\begin{array}{c}52 \\
(67.6)\end{array}$ & $\begin{array}{l}10 \\
(13)\end{array}$ & $\begin{array}{c}15 \\
(19.5)\end{array}$ & 2.08 & 1.04 \\
\hline $\begin{array}{l}\text { 4. Does not provide the opportunity } \\
\text { for professional growth of teachers }\end{array}$ & $\begin{array}{c}52 \\
(67.6)\end{array}$ & $\begin{array}{c}15 \\
(19.5)\end{array}$ & $\begin{array}{c}7 \\
(9.1)\end{array}$ & 3.05 & 1.16 \\
\hline $\begin{array}{l}\text { 5. Does not create confident } \\
\text { environment among teachers }\end{array}$ & $\begin{array}{c}50 \\
(65)\end{array}$ & $\begin{array}{c}8 \\
(10.4)\end{array}$ & $\begin{array}{c}17 \\
(22.1)\end{array}$ & 3.43 & 0.97 \\
\hline & & Mean fo & domain & 3.27 & \\
\hline
\end{tabular}

Results from Table 5 above indicate that nearly 70 percent of the science teachers agreed that the school management was "authoritarian," and "inflexible" in dealing with teachers, and "does not provide the opportunity for teachers' professional growth," all of which recorded a $67.6 \%$ of agreement precisely. The lowest percentage of agreement was reported for the item suggesting the management's giving out inconsiderable decisions that created difficulties for the respondents $(49.4 \%)$. The patterns suggest that this domain is a source of considerable difficulty for science teachers in the governorate. The mean score for this domain is 3.27 , a figure that suggests the respondents' disagreement and dissatisfaction with the school management.

\section{Difficulties Associated with Science Laboratories}

It is generally assumed that effectiveness in science teaching and learning largely depends on practical applications of scientific ideas in the laboratory. Item four in the questionnaire attempted to solicit information about laboratory facilities in the selected schools. The results are indicated below in Table 6.

Table 6

Difficulties Caused by Science Laboratories $(\mathrm{N}=77)$

\begin{tabular}{lcccccc}
\hline \multirow{2}{*}{ Items } & \multicolumn{4}{c}{ Response Categories } & \multirow{2}{*}{$\mathrm{M}$} & \multirow{2}{*}{$\mathrm{SD}$} \\
\cline { 2 - 5 } & $\mathrm{A}$ & $\mathrm{N}$ & $\mathrm{D}$ & & \\
\hline 1. Improper design & 39 & 7 & 20 & 3.04 & \multirow{2}{*}{1.29} \\
& $(50.7)$ & $(9.1)$ & $(40.3)$ & & \\
2. Not meeting safety standards & 45 & 12 & 20 & 3.35 & \multirow{2}{*}{1.02} \\
& $(58.4)$ & $(15.6)$ & $(26)$ & &
\end{tabular}




\begin{tabular}{|c|c|c|c|c|c|c|}
\hline 3. & Not meeting safety standards & $\begin{array}{c}45 \\
(58.4)\end{array}$ & $\begin{array}{c}12 \\
(15.6)\end{array}$ & $\begin{array}{l}20 \\
(26)\end{array}$ & 3.35 & 1.02 \\
\hline 4. & Lack of equipment & $\begin{array}{c}44 \\
(45.5)\end{array}$ & $\begin{array}{c}15 \\
(19.5)\end{array}$ & $\begin{array}{c}17 \\
(31.2)\end{array}$ & 3.45 & 1.24 \\
\hline 5. & Located in unsafe places & $\begin{array}{c}56 \\
(72.7)\end{array}$ & $\begin{array}{c}14 \\
(18.2)\end{array}$ & $\begin{array}{c}6 \\
(7.8)\end{array}$ & 3.82 & 1.02 \\
\hline \multirow[t]{2}{*}{6.} & $\begin{array}{l}\text { Laboratory technician not } \\
\text { doing his duties properly }\end{array}$ & $\begin{array}{c}40 \\
(52) \\
\end{array}$ & $\begin{array}{c}15 \\
(19.5)\end{array}$ & $\begin{array}{c}22 \\
(28.6)\end{array}$ & 3.36 & 1.36 \\
\hline & & & \multicolumn{2}{|c|}{ Mean for domain } & 3.40 & \\
\hline
\end{tabular}

Table 6 above shows that more than 70 percent of the teachers agreed that the laboratories are located in unsafe places. Other major difficulties reported were laboratories' not meeting safety standards (58.4\%), and lacking in equipment (57.2\%). More than half agreed the labs had an improper design (50.7\%), while 52\% were unhappy with their respective lab technicians. The mean scores for this domain is 3.40 , suggesting that the sample was divided or mostly uncertain on this issue.

\section{Summary of Difficulties}

The following table (Table 7) illustrates the major difficulties faced by science teachers in the selected schools in Kuwait.

Table 7

Major Difficulties Faced by Science Teachers in Kuwait $(\mathrm{N}=77)$

\begin{tabular}{|c|c|c|c|}
\hline Domain & & Difficulties & $\%$ \\
\hline \multirow[t]{2}{*}{$\begin{array}{l}\text { Curriculum } \\
\text { Objectives }\end{array}$} & a) & $\begin{array}{l}\text { Does not include all domains (i.e., } \\
\text { cognitive, affective and psychomotor) }\end{array}$ & 49.4 \\
\hline & b) & $\begin{array}{l}\text { Does not follow domains levels (from the } \\
\text { lowest order to the highest order) }\end{array}$ & 39.0 \\
\hline \multirow{2}{*}{$\begin{array}{l}\text { Student } \\
\text { Assessment }\end{array}$} & a) & Does not follow curriculum objectives & 58.4 \\
\hline & b) & Not consistently applied & 57.2 \\
\hline \multirow{3}{*}{$\begin{array}{l}\text { School } \\
\text { Management }\end{array}$} & a) & Authoritarian in dealing with teachers & 67.6 \\
\hline & b) & Inflexible in dealing with teachers & 67.6 \\
\hline & c) & $\begin{array}{l}\text { Does not provide the opportunity for } \\
\text { professional growth of teachers }\end{array}$ & 67.6 \\
\hline \multirow{3}{*}{$\begin{array}{l}\text { Science } \\
\text { Laboratories }\end{array}$} & a) & Located in unsafe place & 72.7 \\
\hline & b) & Does not meet safety standards & 58.4 \\
\hline & c) & Lacks equipment & 57.2 \\
\hline
\end{tabular}

\section{Gender Differences in Teachers' Perceptions of Difficulties}

In addition to the above descriptive analysis, a set of bivariate analyses was run to find out whether these difficulties faced by the science teachers varied with gender. The first set of results pertaining to perceived difficulties associated with curriculum objectives are illustrated in Table 8. 
Table 8

Gender Differences in Perceived Difficulties Related to Curriculum Objectives ( $\mathrm{N}=77$ )

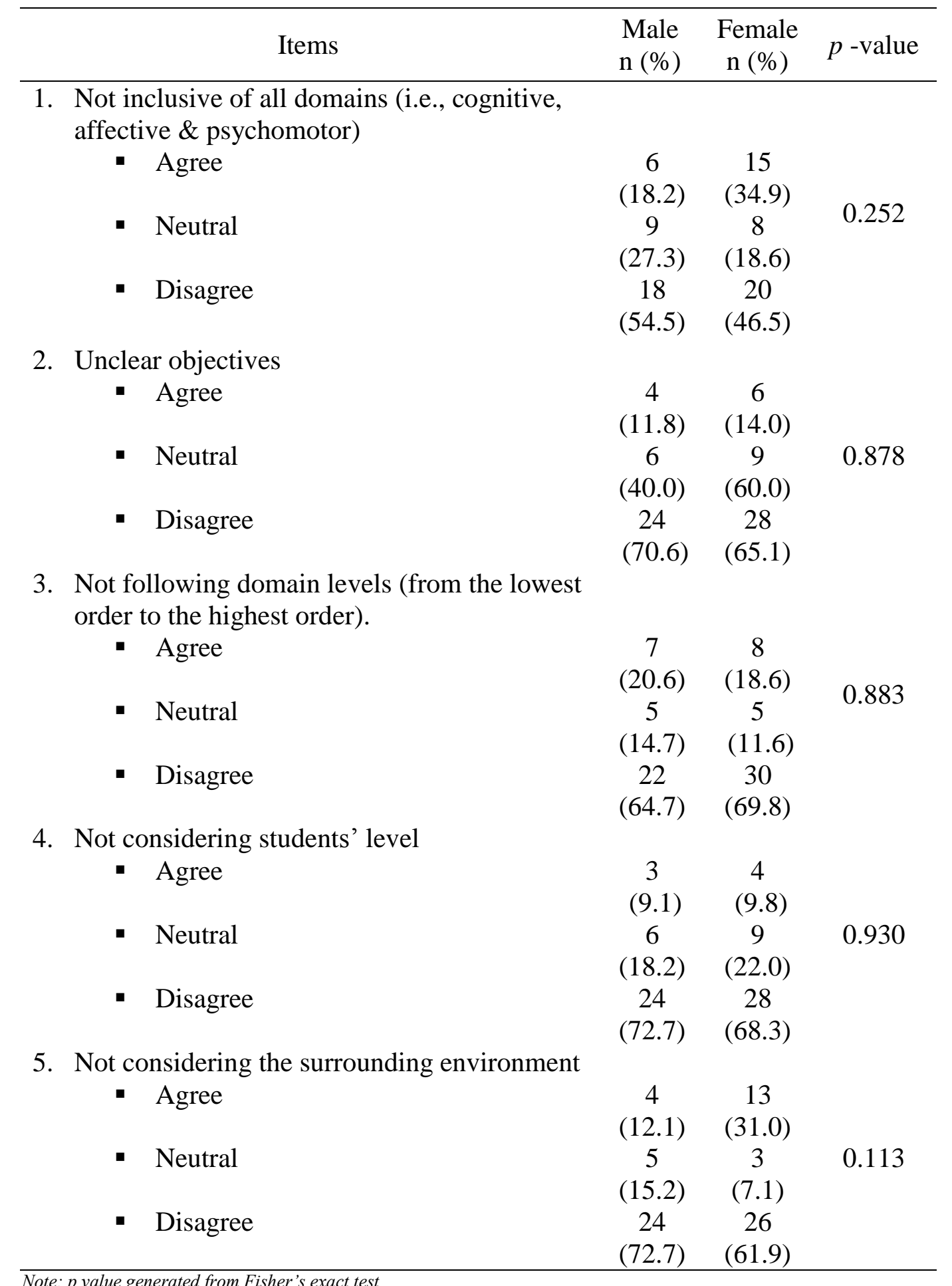

Note: $p$ value generated from Fisher's exact test

Chi-square test was used to determine whether there were gender differences in the teachers' perceptions of difficulties associated with curriculum objectives. The results showed no statistically significant differences between male and female science teachers in this domain.

The second set of results pertaining to perceived difficulties associated with student assessment are illustrated in Table 9. 
Table 9

Gender Differences in Perceived Difficulties Related to Student Assessment ( $=77)$

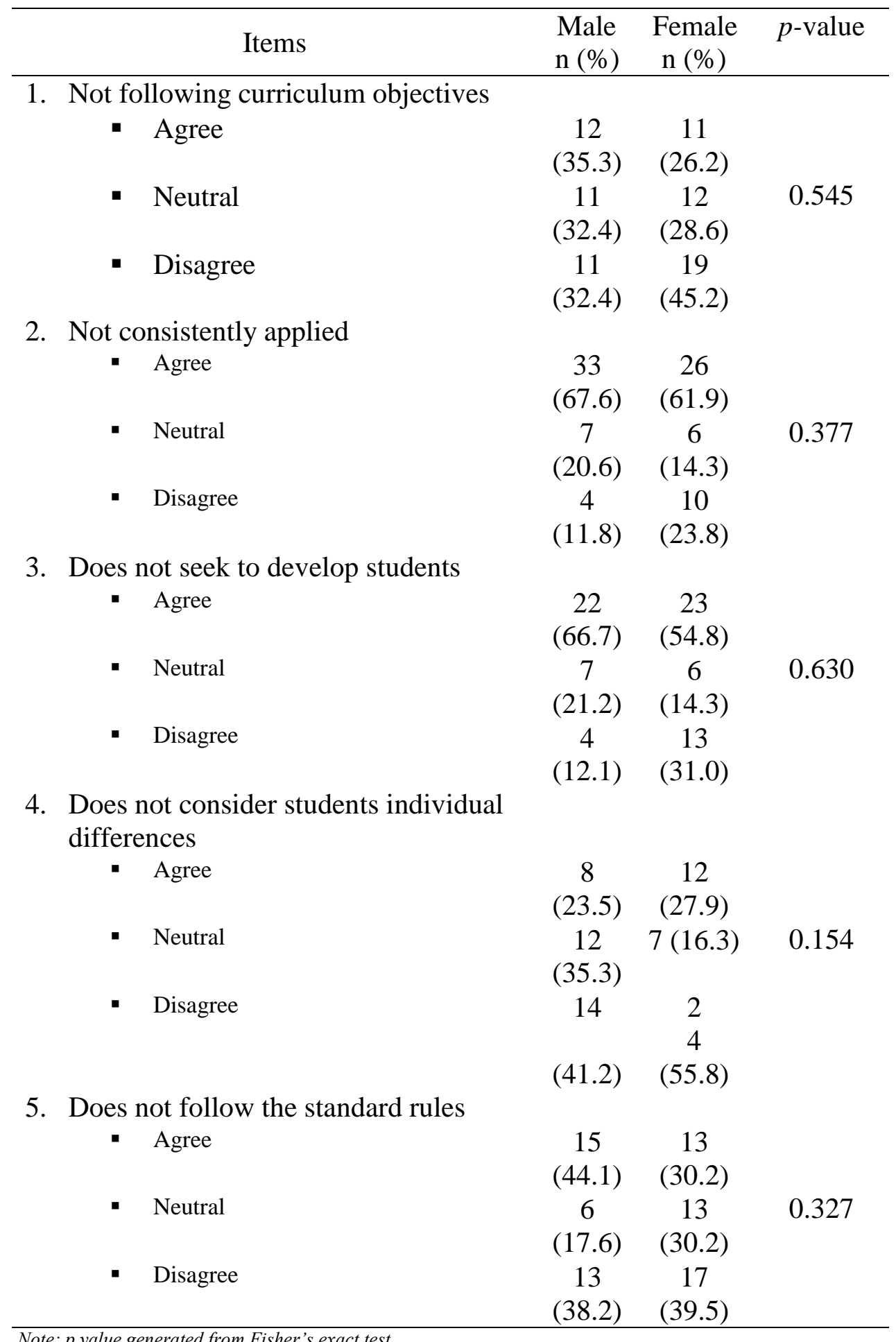

Results in Table 9 reveals that gender was not significantly associated with the perceived difficulties related to student assessment ( $p>0.05)$. The chi-square results shown in Tables 10 also indicate no gender differences in regard to perceived difficulties caused by the school management. 
Table 10

Gender Differences in Perceived Difficulties Related to School Management $(\mathrm{N}=77)$

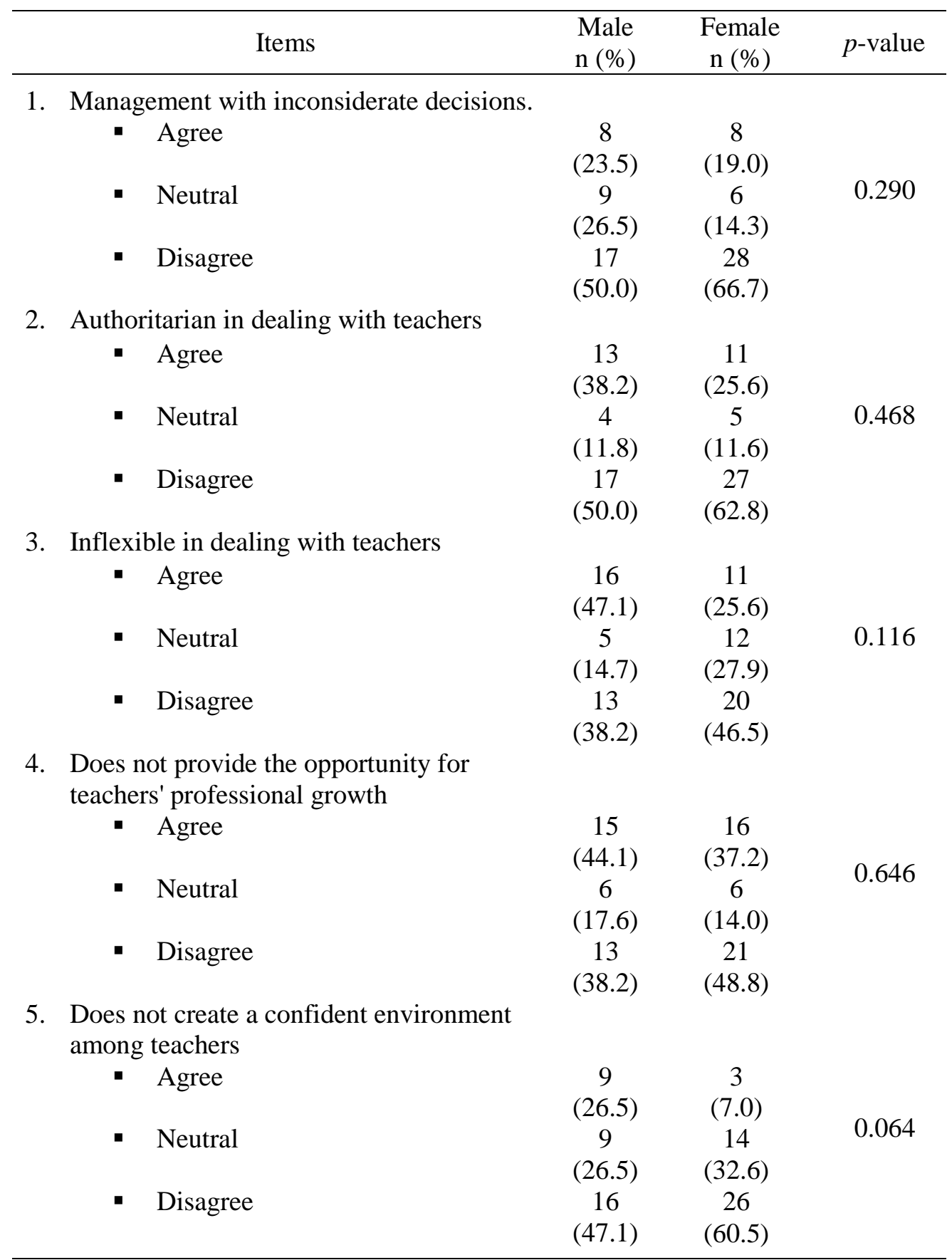

Note: $p$ value generated from Fisher's exact test

Table 11 demonstrates no statistically significant differences at $p=.05$ between male and female teachers in regard to the difficulties caused by science laboratories.

Table 11

Gender Differences in Perceived Difficulties Related to Science Laboratories ( $\mathrm{N}=77$ )

\begin{tabular}{cccc}
\hline \multirow{2}{*}{ Items } & $\begin{array}{c}\text { Male } \\
\mathrm{n}(\%)\end{array}$ & $\begin{array}{c}\text { Female } \\
\mathrm{n}(\%)\end{array}$ & $p$-value \\
\hline
\end{tabular}

1. Improper design

$\begin{array}{lccc}\text { - Agree } & 14 & 17 & \\ \text { - Neutral } & (41.2) & (39.5) & 0.256 \\ & 1 & 6 & \\ & (2.9) & (14.0) & \end{array}$


- Disagree

2. Not meeting safety standards

- Agree

- Neutral

- Disagree

3. Lack of equipment

- Agree

- Neutral

- Disagree

4. Located in unsafe place.

- Agree

- Neutral

- Disagree

5. Laboratory technician does not properly do his duties.

- Agree

- Neutral

- Disagree
$19 \quad 20$

(55.9) (46.5)

$\begin{array}{cc}10 & 10 \\ (29.4) & (23.3) \\ 8 & 4 \\ (23.5) & (9.3) \\ 16 & 29 \\ (47.1) & (67.4)\end{array}$

0.585

11

(17.6) (26.2)

$8 \quad 7$

(23.5) (16.7)

$20 \quad 24$

(58.8) (57.1)

0.156

1

$\begin{array}{cc}(14.7) & (2.4) \\ 5 & 9\end{array}$

(14.7) (21.4)

$24 \quad 32$

(70.6) (76.2)

0.088

$14 \quad 8$

(41.2) (18.6)

69

(17.6) (20.9)

$14 \quad 26$

(41.2) (60.5)

\section{Discussion and Conclusion}

The first conclusion that can be drawn from our findings regarding research question 1, "What are the difficulties facing science teachers caused by curriculum objectives?" we found that almost half of the science teachers $(49.4 \%)$ agreed that the science curriculum objectives failed to include all the important domains covering cognitive, affective, and psychomotor learning. Many agreed the objectives were unclear and did not follow the proper levels showing the progression of learning from the lowest order to the highest order. These would be the most problematic aspects related to the science curriculum objectives. Other aspects, i.e. the objectives' failure to consider students' ability level (22.1\%) and the surrounding environment $(18.2 \%)$, were seen by fewer teachers as being problematic.

Al Enizi (2009) reached the same conclusion in his study--that the objectives of Kuwaiti schools' science curriculum were only focused on the cognitive aspects, neglecting the other two important domains of learning. In an earlier research, Al-Kandari (2006) found that 91.2\% of the curriculum objectives tend to concentrate on the cognitive domain, and almost all the cognitive objectives (95.2\%) focused on knowledge level (the lowest level). Al Enizi (2009) also felt that the science curriculum objectives needed to be made more specific for teachers. This is necessary to help them to implement the curriculum more effectively. 
The second conclusion reached, i.e. in regard to the question, "What are the difficulties facing science teachers caused by student assessment system?", is that the assessment is not well- aligned with the curriculum objectives. About 58\% had this perception, while a similar percentage (57.2\%) agreed there is inconsistency in how student assessment is implemented in science classrooms in the governorate. Furthermore, many teachers perceived a departure from the standard rules $(54.4 \%)$ in the existing assessment practices. The practices should be improved or reformed as currently, they do not consider students' individual differences (44.2\%) and do not help to develop their learning (42.9\%).

Our results confirmed the results of Skilbeck (1971), who stated that without clear and precise curriculum objectives, it is difficult to prepare an effective assessment system. Much earlier works, i.e. those of Dagher and BouJaoude (2011) and Sabah (1998), had highlighted a disconnect between student assignment and curriculum objectives. Our results also support the findings of Al Enizi (2009) who reported the many difficulties that science teachers faced with student assessment due to inconsistencies in the prevailing practices.

The third conclusion reached, that pertains to research question 3, "What are the difficulties facing science teachers caused by school management?" is that a large majority of the science teachers reported their respective school management as rigid and unsupportive. They felt the school management are authoritarian and inflexible in dealing with them, and does not provide the learning opportunities necessary to promote their professional growth. Additionally, the management has not created a conducive working environment for the teachers, one that would boost their confidence. Teachers also had to do deal with the management's inconsiderate decisions in important matters.

These conclusions were earlier reached by Al-Momani (2017), Kaptan and Timurlenk (2012), Kadbeya et al. (2015), and Parker et al. (2018). These previous studies all found that teachers need more training during their service. It was also noted in Sabah (1998) that many science teachers perceived their school management to have failed in creating a professional working environment, while Alotabi (2007) discovered that authoritarianism seemed to characterize how school management often dealt with teachers. Another reason for teachers' dissatisfaction could be the lack of professional development training provided to them by the school management, that is, courses and programs aimed at promoting professional growth and enhancing instructional competency among teachers. Furthermore, creating a competitive environment by some school managements leads to strained relationships, which will affect teachers' productivity, hence causing the loss of psychological stability among them.

The fourth conclusion, pertaining to the question, "What are the difficulties facing science teachers caused by science laboratory?" is that the majority of the science teachers surveyed were unhappy with science laboratories, primarily because they are not located in safe places $(72.7 \%)$, do not meet safety standards (58.4\%), lack science equipment $(57.2 \%)$, and lack a proper design $(50.7 \%)$. The respondents were also dissatisfied with their lab technicians $(52 \%)$.

Dogu, Dinc and Meydan (2007) had earlier reached similar results. In their study, 74\% of the respondents' schools did not furnish students with proper equipment for the conduct of science experiments. This was also reported in Awan (2015) in which half of the sample of teachers expressed dissatisfaction with the science labs and equipment. In Mahmoud (2010) and Adwan (1999), teachers were discouraged by incapable lab technicians and the lack of technical support as they felt their own teaching, as well as student learning, was quite affected by these inadequacies (Mahmoud, 2010). The difficulties caused by science laboratories could be due to the fact that recently, the science curricula in Kuwaiti schools undergo frequent 
changes. This in turn affects schools' ability to provide equipment that is up to date with the changes made to the new science curricula. Moreover, many schools in Kuwait do not update and maintain their facilities regularly, especially schools that have been built for more than twenty years. The science labs' lack of maintenance, which certainly influences their general appearance, could have caused teachers to perceive that they are less than safe, or that they are not located in safe places.

The study also concluded that there are no significant differences between male and female science teachers in the difficulties they faced caused by curriculum objectives, student assessment system, school management, and science laboratories. Although male and female science teachers are segregated from each other in Kuwaiti schools, both shared the same perceptions regarding the difficulties they faced. The reason could be that the schools are managed by the same administration and governed by the same policies, which are similarly enforced upon them by the Ministry of Education and science education supervisors. This was also noted in Sabah (1998) and Saleh (1999). Both studies concluded that there are no significant gender differences in teachers' perceptions of the difficulties they encountered in science teaching.

\section{RECOMMENDATIONS}

The outcomes of this study are insightful, and will be of help to the Ministry of Education in Kuwait. They should pay attention to the difficulties affecting Kuwait's science teachers as it affects the quality of science teaching and learning. Drawing upon the results, the study gives the following recommendations:

a) Curriculum objectives need to be explicit, precise, and clearly formulated, and must cover all learning domains encompassing the cognitive, affective, and psychomotor aspects.

b) It is important that student assessment be consistently and regularly administered. It should also be checked to ensure alignment with curriculum objectives. Furthermore, when developing student assessment procedures, their quality and effectiveness must be ascertained prior to administration.

c) School managements have to change their authoritarian and inflexible administration style to a more democratic and flexible style when it comes to dealing with teachers. Continuous training programs and courses should be provided by professionals in the field for teachers and management members, where mandatory training programs are a requisite for promotion. Additional professional development workshops are necessary, especially for in-service teachers to improve their teaching skills. Schools managers need training courses offered by professionals in the techniques and strategies of managing staff and human resource.

d) The Ministry of Education must design proper science laboratories, and choose the right locations for them in the school premises. For safety reasons, they must also perform periodic maintenance of these labs.

e) Specific safety features have to be added to the existing laboratories, while both technicians and science teachers must receive training on how to use these features. Moreover, providing laboratories with the most common and basic scientific equipment and demonstrating their appropriate use are highly recommended. 


\section{REFERENCES}

Al-Momani, F. (2017). Difficulties in Making Professional Science Teacher in the 21th Century. IOSR Journal of Research \& Method in Education (IOSR-JRME), 7(1), 76-82.

Adebayo, O., \& Osmond, I. (2010). A search for an acceptable margin of valuation error: A case study of valuers and their clients in Nigeria. Sri Lanka Journal of Real Estate, 1(4), 54-73.

Adu-Gyamfi, K. (2014). Challenges faced by science teachers in the teaching of integrated science in Ghanaian junior high schools. Journal of Science and Mathematics Education, 6(2), 59-80.

Adwan, A. (1999). Difficulties facing the use of school laboratories in the tenth grade according to teachers of public schools in Nablus (Master's Thesis). An-Najah National University. Palestine.

Al Enizi, L. (2009). Problems of Science Teaching in Primary schools in the City of Arar (Master's thesis). Umm Al-Qura university.

Al Kandari. A. (2006). To what extent science education objectives are presented in science teacher's lesson plan in Kuwait schools. Educational Journal in Kuwait. 20(80), 69-98.

Alotabi, M. (2007). School climate and its obstacles and its role in the performance of teachers in public schools. Naif Arab University for Security Sciences, Riyadh

Anderman, E., Sinatra, G., \& Gray, D. (2012). The challenges of teaching and learning about science in the twenty-first century: Exploring the abilities and constraints of adolescent learners. Studies in Science Education, 48(1), 89-117.

Awan, M. (2015). Physical conditions of science laboratories and problems faced by science teachers in conducting practicals in punjab. Bulletin of Education and Research, 37(1), 47-54.

Cansiz, N., \& Cansiz, M. (2015). The challenges faced by preservice science teachers during teaching practice. The Eurasia Proceedings of Educational \& Social Sciences (EPESS), 2, 40-42.

Chavan, R. (2013, Oct 18-19). Difficulties Encountered by Science Teachers during Teaching Concepts of Science. Paper presented at the National Conference on challenges in teacher education.

Conroy, R. (2006). Sample size: a rough guide. Retrieved from https://pdfs.semanticscholar.org/4781/878153e13322c028c7d8970e7f52fbaa102a.pdf.

Dagher, Z., \& BouJaoude, S. (2011). Science education in Arab states: Bright future or status quo? Studies in Science Education, 47(1), 73-101.

Dogu, S., Dinc, M., Meydan, A. (2007). Difficulties science teachers at elementary school level experience in science instruction in turkey. Humanity \& Social Sciences Journal, 2(2), 86-92. 
General Secretariat of the Supreme Council for Planning and Development in Kuwait. (2016). The Analysis of educational costs and expenditure. Secretariat for Planning Affairs. Kuwait.

Goe, L., Bell, C., \& Little, O. (2008). Approaches to Evaluating Teacher Effectiveness: A Research Synthesis. National Comprehensive Center for Teacher Quality.

Habib, H. (2017). A study of teacher effectiveness and its importance. National Journal of Multidisciplinary Research and Development, 2(3), 530-532.

Johnson, T., \& Wells, L. (2017). English language learner teacher effectiveness and the Common Core. Education policy analysis archives, 25(23).

Kadbey, H., Dickson, M., \& McMinn, M. (2015). Primary teachers' perceived challenges in teaching science in Abu Dhabi public schools. Procedia-Social and Behavioral Sciences, 186, 749-757.

Kaptan, K., \& Timurlenk, O. (2012). Challenges for Science Education. Procedia - Social and Behavioral Sciences, 51, 763-771.

Kola, A., Sunday, O., \& Ayinde, G. (2015). Teachers' effectiveness and its Influence on students' learning. Advances in Social Sciences Research Journal, 2(4), 88-95.

Mahmoud, M. (2010). Difficulties faced by science teachers in using the laboratory. Diyala Journal, 45, 426-441.

Martin, M., Mullis, I., Foy, P., \& Hooper, M. (2016). TIMSS 2015 International Results in Science. International Association for the Evaluation of Educational Achievement. Boston College.

Marulcu, i., \& Bozkus, K. (2017). Adaptation of the teacher effectiveness scale in higher education into Turkish language. European Journal of Education Studies, 3(10), 284292.

Omair, A. (2014). Sample size estimation and sampling techniques for selecting a representative sample. Journal of Health Specialties, 2(4), 142, 142-147.

Owoh, T. (2016). Teacher Effectiveness as Correlate of Students' Cognitive Achievement at Upper Basic Education in Basic Technology. Journal of Education and Practice, 7(29), 120-124.

Pan, C. (2017). On Scientific Literacy Development: Exploring Challenges of Science Teaching in Elementary School Teachers (Master's thesis). Ontario Institute for Studies in Education of the University of Toronto.

Parker, J., Sei-Himah, V., Asare, I., \& Ackah, J. (2018). Challenges Faced by Teachers in Teaching Integrated Science in Junior High Schools in Aowin Municipality-Ghana. Journal of Education and Practice, 9(12), 65-68.

Robinson, D., \& Lewis, C. (2017). Typologies for Effectiveness: Characteristics of Effective Teachers in Urban Learning Environments. Journal of Urban Learning, Teaching, and Research, 13, 124-134. 
Sabah, M. (1998). The educational problems faced by science teachers in the basic and secondary schools in Palestine (Master's thesis). An-Najah National University. Palestine.

Saleh, E. (1999). Educational difficulties in teaching science according to teachers in Nablus Governorate (Master's thesis). An-Najah National University. Palestine.

Simons, J. (2016) The Importance of Teachers: A collection of essays on teacher recruitment and retention, Policy Exchange, Clutha House, 10 Storey's Gate, London SW1P 3AY.

Skilbeck, M. (1971). Preparing curriculum objectives. The Vocational Aspect of Education, 23(54), 1-7.

Stutchbury, K., \& Katabaro, J. (2011, Aug 3-5). TESSA secondary science: addressing the challenges facing science teacher-education in Sub-Saharan Africa. Paper presented at DETA Conference, Maputo, Mozambique 